ZOOLOGIA 29 (5): 397-404, October, 2012

doi: $10.1590 /$ S1984-46702012000500002

\title{
Reproductive biology of Sciades herzbergii (Siluriformes: Ariidae) in a tropical estuary in Brazil
}

\author{
Fernando R. Queiroga', Jéssica E. Golzio', Raphaela B. dos Santos ${ }^{1}$, \\ Tayná O. Martins ${ }^{1} \&$ Ana Lúcia Vendel ${ }^{1,2}$
}

\author{
${ }^{1}$ Universidade Estadual da Paraíba, Campus V, CCBSA. Rua Horácio Trajano de Oliveira, Cristo Redentor, 58020-540 João \\ Pessoa, PB, Brazil. \\ ${ }^{2}$ Corresponding author. E-mail: analuciavendel@gmail.com
}

\begin{abstract}
The present study investigated the reproductive biology of Sciades herzbergii in the Paraíba do Norte River Estuary, Brazil. We aimed to characterize the reproduction of the species with respect to sex ratio, spawning season, condition factor and length at first maturity. Specimens were captured between August 2009 and July 2010 in a stretch of the main channel of the estuary. In the laboratory, they were measured, weighed and macroscopically classified with regard to sex and gonad development stage, and their gonads were weighted. The monthly distribution of the sexes and their respective stages of maturation were determined. The gonadosomatic index (GSI), condition factor (K) and the length at first maturity were calculated for males and females. The sex ratio was determined monthly and throughout the entire study period and the chi-square test was used to evaluate if the sex ratio differed from 1:1. The Pearson's correlation test was used to determine the correlation between GSI and K values. A total of 260 individuals were captured. It was impossible to determine the sex of 32 individuals, possibly due to their young age. The sex ratio did not differ throughout the overall study period, but significant differences were found in December and May, with a predominance of females, and in March, when males predominated. Spawning activities were concentrated between December and March, as determined by the greater incidence of mature females and higher GSI values. The spawning of the S. herzbergii population is characterized as staggered due to its long duration. For females, $\mathrm{K}$ values were not significantly correlated with the GSI, but the decrease in $\mathrm{K}$ values in the spawning period indicates that energy is being spent in reproduction. With regard to males, the distribution of developmental stages did not follow the same clear pattern as that seen with females. However, the GSI indicated a greater investment in gonads in October, with a decrease up to July (end of the data acquisition period). For males, K values exhibited a positive correlation with GSI, with a gradual decrease beginning in February up to July, indicating energy that energy was being consumed, which was certainly related to the mouth brooding of eggs and neonates. Mean length at first maturity was $212 \mathrm{~mm}$ for females and $240 \mathrm{~mm}$ for males. Sciades herzbergii completes its lifecycle in the estuary and exhibits post-spawning parental care. This species is abundant in the estuary studied and information on the reproductive biology of this resident is necessary to the management of the estuarine environment.
\end{abstract}

KEY WORDS. condition factor; gonadosomatic index; mean length at first maturity; Paraíba do Norte River Estuary; pemecou sea catfish; spawning period.

Estuaries play an important role in the maintenance of biological productivity and diversity, being essential habitats for many species of fish that live in these environments during part or all of their lifecycles (BLABER 2000). Fish make use of estuaries essentially as a feeding ground, breeding ground and/or nursery for larvae and juveniles. Thus, the community of estuarine fish is made up of migrant, resident and occasional species (Albaret \& Diouf 1994, Andrade-Tubino et al. 2008, Vendel et al. 2010). The majority of Ariidae fish, which are known as marine catfish, inhabit shallow coastal areas and estuaries in tropical and temper- ate regions (MARCENIUK 2007). The most abundant species of the family use different strategies for coexistence in these environments, especially temporal separation with regard to spawning, and some degree of feeding segregation (Gomes et al. 2001).

Studies addressing sex ratios, the determination of stages of the reproductive cycle and the length at first maturity are fundamental to the description and understanding of the breeding pattern of a species in its habitat. Determining the lifecycle strategies of fish allows a better understanding of how species adapt to different environments (VAzZOLER 1996). 
The target species of this study, Sciades herzbergii (Bloch, 1794) is known as pemecou sea catfish and occurs along the Atlantic coast of South America from Colombia to northeastern Brazil, including the state of Bahia (MARCeniuk 2005). This omnivorous species is considered a second-order consumer and specialist in the predation of brachyuran crabs (KRUMME et al. 2008). The pemecou sea catfish is a benthic resident in estuarine waters and one of the dominant fish species in intertidal mangrove creeks in northern and northeastern Brazil (BARLETTA et al. 2003, Krumme et al. 2004, Giarrizzo \& Krumme 2007, AndradeTubino et al. 2008), with considerable influence on the dynamics of these ecosystems. Although not valued commercially, this species is an important protein source in riverine communities in northeastern Brazil at the subsistence level, due to its abundance in estuaries (BARletTA \& COSTA 2009).

The present study characterizes the reproductive biology of $S$. herzbergii in Paraíba do Norte River Estuary in the state of Paraíba, Brazil, with a description of sex ratios, gonad development stages, spawning season and length at first maturity.
Moreover, gonadosomatic index and condition factor values were determined in order to analyze fluctuations in nutritional conditions and the association of these fluctuations with reproductive activity.

\section{MATERIAL AND METHODS}

The Paraíba do Norte River Estuary is located between the municipalities of Bayeux and João Pessoa in the state of Paraíba, northeastern Brazil (Fig. 1). Specimens of S. herzbergii were caught along a stretch between the UE point (upper estuary - $07^{\circ} 07^{\prime} 13^{\prime \prime} S$ and $34^{\circ} 54^{\prime} 51^{\prime \prime} \mathrm{W}$ ) and the LE point (lower estuary - 07 $01^{\circ} 59^{\prime \prime} \mathrm{S}$ and $34^{\circ} 51^{\prime} 45^{\prime \prime} \mathrm{W}$ ) in the one-year period spanning from August 2009 to July 2010. The mangrove in the region is composed of five dominant plant species: Rhizophora mangle, Avicennia germinans, A. schaueriana, Laguncularia racemosa and Conocarpus erectus. Despite the removal of mangrove wood by riverine human populations and the increasing degree of urbanization, the environment is still in a good state of conservation.

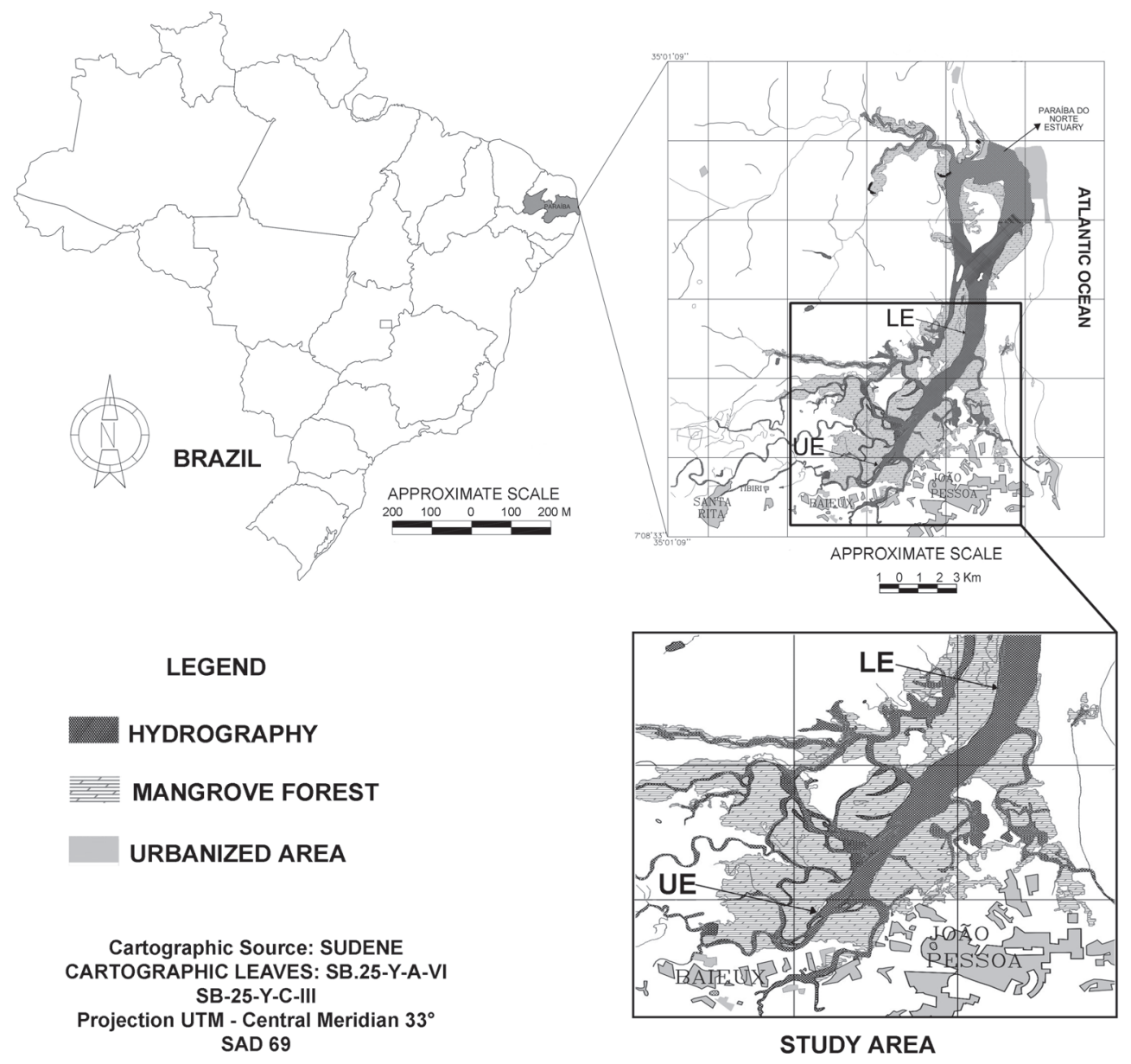

Figure 1. Geographical location of Paraíba do Norte River Estuary, Brazil. (LE) Lower Estuary, (UE) Upper Estuary. 
To describe the hydrological conditions of the study area, monthly values were determined for the following variables at each sampling point: water temperature, $\mathrm{pH}$, salinity and water transparency, determined by a Secchi disk.

The specimens were caught monthly at low tide with two types of gear deployed in marginal areas of the estuary: a) beach seines ( $8 \mathrm{~m}$ in length and $2 \mathrm{~m}$ in height; mesh size: $12 \mathrm{~mm}$ between opposing knots) and b) "tomada", a net traditionally used by local fishermen, consisting of the installation of a long net alongside a small channel in the estuary at low tide; at high tide, the net is suspended to catch the fishes within the mangrove, preventing them from leaving the channel at the next low tide. This technique is non-selective and is widely used by local fishermen, as it ensures the capture of a large amount of fish.

The specimens were kept in ice and transported to the laboratory where they were identified (MARCENIUK 2005) and had their total weight $(0.1 \mathrm{~g})$ and total length $(\mathrm{mm})$ measured. The specimens were then opened with an abdominal incision, and the gonads were examined for the determination of the sex and the maturation stage (VAzzoler 1996).

After the determination of sex and maturation stage, the gonads were then removed and weighed on a digital scale $(0.001$ g). The sex ratio was determined on monthly basis and the chisquare test $\left(\chi^{2}\right)$ with a $5 \%$ significance level was used to evaluate if sex ratio differed from 1:1. The percentage frequency of each development stage in the period was determined. For the determination of the participation of the gonads in the total body weight of each specimen, the gonadosomatic index (GSI) was calculated using the following equation GSI $=$ GW/TW $x$ 100 , in which GW is gonad weight and TW is the total weight of the individual. The allometric condition factor $(\mathrm{K})$ was calculated to determine the health of the fish throughout the year, using the formula $\mathrm{K}=\mathrm{BW} / \mathrm{TL}^{\mathrm{b}}$, in which $\mathrm{BW}$ is body weight (total weight minus gonad weight) and $\mathrm{b}$ is the regression coefficient between BW and TL (total length). Mean GSI and K values were displayed on graphs, on which respective mean trend slopes were plotted. The correlation between these values was determined using Pearson's correlation test with the aid of the BioEstat 5.0 software.

Regional monthly rainfall was estimated for the Lower Paraíba basin (downstream from the Acauã dam, which is the last dam on the Paraíba River and holds all upstream water, except in very rainy years). Rainfall data for the 30 days prior to sampling was obtained from the Proclima database (INPE/ CPTEC 2012) for eight of 38 municipalities along the Paraíba Basin. Regional rainfall was estimated from the total values at rainfall gauge stations located downstream from the Acauã dam (Salgado de São Félix, Itabaiana, Pilar, São Miguel de Taipú, Cruz do Espírito Santo, Bayeux, Santa Rita and João Pessoa). These data were compared with the GSI of $S$. herzbergii females using Pearson's correlation test to determine a possible association with reproduction activity.
Mean length at first maturity $\left(\mathrm{L}_{50}\right)$ was calculated by the distribution of the cumulative percentage of adults (stages B, C and D) in seventeen $15 \mathrm{~mm}$ length classes for a total of 89 females and 50 males. The values were then plotted and submitted to allosteric sigmoidal graphic adjustment using the software GraphPad Prism 5.0, which determined the length at which $50 \%$ of the population was in reproductive activity.

\section{RESULTS}

The mean observed hydrological conditions at the study area were: water temperature $(29.03 \pm 1.20$, range: 26.8 to $\left.31.6^{\circ} \mathrm{C}\right), \mathrm{pH}(7.39 \pm 0.67$, range: 5.97 to 8.57$)$, salinity $(15.13 \pm$ 7.62 , range: 5.0 to 40.0 ) and water transparency (56.59 \pm 22.89 $\mathrm{cm}$, range: 20 to $120 \mathrm{~cm}$ ).

Between August 2009 and July 2010, 228 specimens of $S$. herzbergii whose sex could be identified were selected for this study. This sample included 123 females and 105 males. For this sample, mean total weight was $139.57 \pm 113.93 \mathrm{~g}$ (range: 9.0 to $597.2 \mathrm{~g}$ ) for females and $114.42 \pm 90.39 \mathrm{~g}$ (range: 6.7 to $372.9 \mathrm{~g}$ ) for males. Mean total length was $228.21 \pm 59.75 \mathrm{~mm}$ (range: 100 to $370 \mathrm{~mm}$ ) for females and $214.42 \pm 60.47 \mathrm{~mm}$ (range: 90 to $340 \mathrm{~mm}$ ) for males.

Based on visual morphological characteristics, this study has identified four gonad development stages for catfishes: Immature (A): no participation in reproduction; ovaries occupy less than $1 / 3$ of the body cavity, are filamentous, translucent and have little vascularization, but are more vascularized than the testicles; no oocytes are visible to the naked eye; testicles are slightly whitish; Maturing (B): ovaries are larger, occupying between $1 / 3$ and $1 / 2$ of the cavity; with a sac-like shape and more intensive vascularization than in stage A; small oocytes are visible to the naked eye; testicles exhibit more intense white coloration and are more robust; Mature (C): large ovaries, occupying $1 / 2$ to $2 / 3$ of the body cavity; are quite turgid and of orange coloration due to large size of the oocytes ( 0.5 to $1.0 \mathrm{~cm}$ in diameter); testicles are quite turgid, with characteristic milky coloration; Spawned (D): ovaries occupy less than $1 / 3$ of the body cavity, with sac-like shape, but rather flaccid; hemorrhagic appearance, with occasional presence of small oocytes; testicles have oval format and hemorrhagic appearance, but less intensively in comparison to the ovaries in this stage.

The sex ratio in the population sampled was not significantly different from $1: 1\left(\chi^{2}=1.421 ; \mathrm{p}=0.233\right)$. In the analysis by month, females were predominant between August and February (except in September and November, in which no females were caught) and again in May (Fig. 2). Males accounted for the majority of specimens captured between March and July, except May. The monthly proportion between females and males only differed significantly in December and May, when females predominated, as well as in March, when males predominated $(\mathrm{p}<0.05)$. 


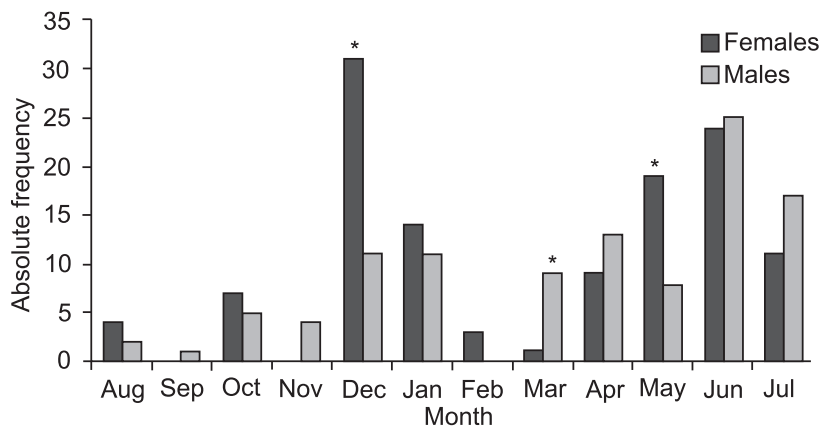

Figure 2. Distribution of S. herzbergii by sex between August 2009 and July 2010 in Paraíba do Norte River Estuary, Brazil. * Months in which sex ratio differed significantly from 1:1 $(p<0.05)$.

The distribution of $S$. herzbergii females based on macroscopic gonad development stage (Fig. 3) revealed that the immature stage predominated in August and October. Females in reproductive activity predominated in December and March, but occurred in other months as well. The spawned stage was observed more frequently between April and July. With regard to male gonad development (Fig. 4), stages A and B were ob-
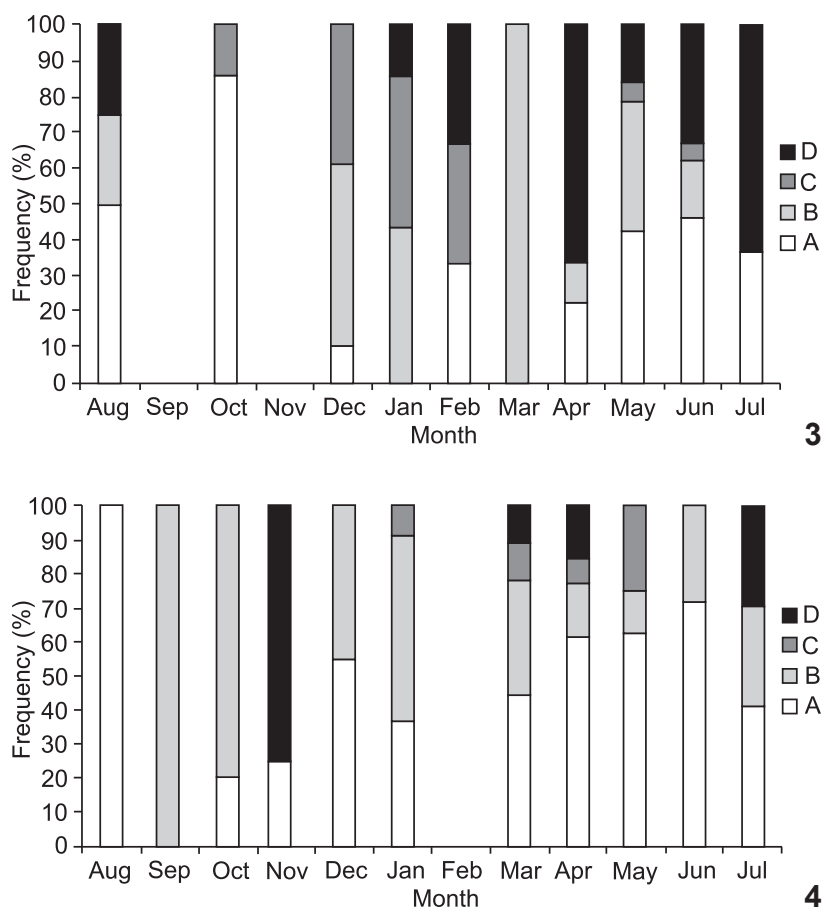

Figures 3-4. Monthly variation in frequencies of gonad development stages for S. herzbergii females (3) and males (4) in Paraíba do Norte River Estuary, Brazil. A: immature, B: maturing, C: mature, D: spawned stages. served on most months. Maturing specimens were found in small percentages between March and May and spawned individuals were found in November, March, April and July.

The GSI was calculated for the 109 female individuals for which ovarian weight was determined. The trend slope (Fig. 5) revealed an increase in energy investment in the gonads beginning in December, with a peak in February and a decline at the end of March. The GSI of males was calculated using 80 individuals in which gonad weight was determined. High values were found in October, December and January, with a subsequent decline through to end of the data acquisition period (Fig. 6).
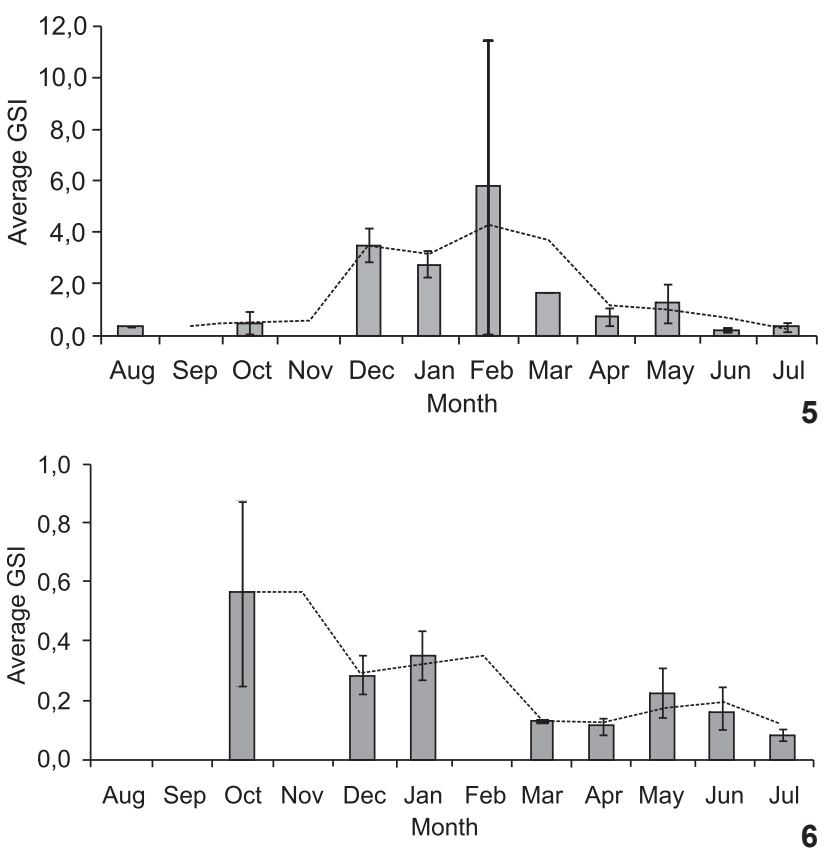

Figures 5-6. Mean + standard error of GSI and respective trend slopes (dashed line) for S. herzbergii females (5) and males (6) in Paraíba do Norte River Estuary, Brazil.

The condition factor $(\mathrm{K})$ was calculated for the same specimens used for the GSI. The trend slope for the monthly K for females (Fig. 7) revealed higher values between August and October, followed by a decline through to February, an increase through to April and stable values between May and July. The monthly $\mathrm{K}$ for males (Fig. 8) tended toward a decline from August to May, followed by stable values through to the end of the data acquisition period. There was no significant correlation between GSI and K values for females ( $\mathrm{n}=109, \mathrm{r}=-0.512$, $\mathrm{p}>0.05)$, whereas a significant positive correlation was found for males $(\mathrm{n}=80, \mathrm{r}=0.832, \mathrm{p}<0.05)$.

Figure 9 displays the total rainfall values in the study period. An increase in rainfall was observed beginning in January, which was prolonged until the end of the data acquisition 

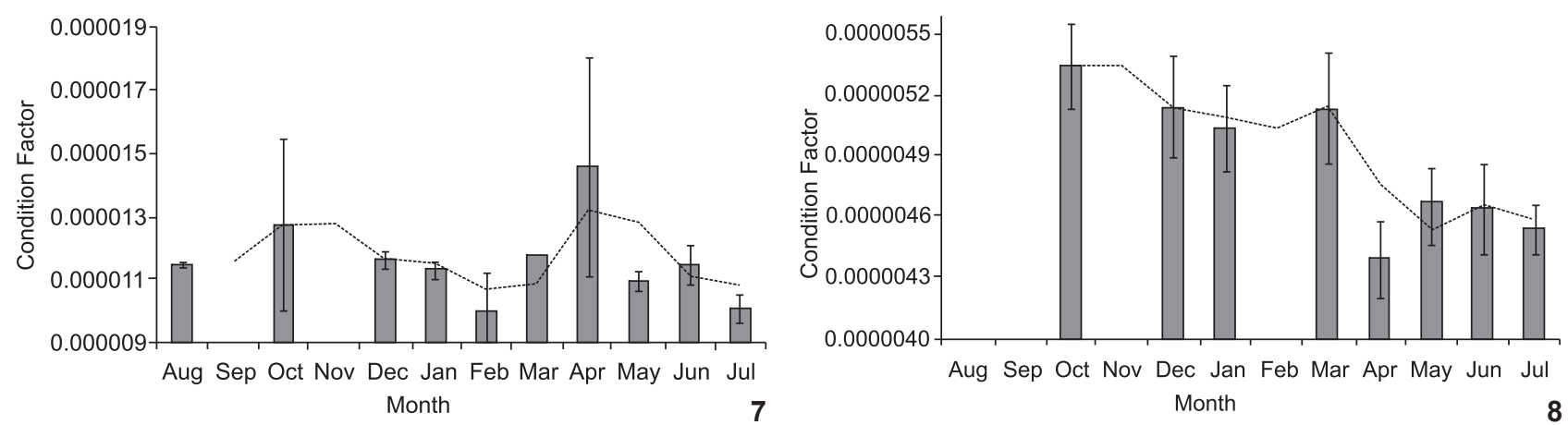

Figures 7-8. Monthly condition factor + standard error and respective trend slopes (dashed line) for S. herzbergii females (7) and males (8) in Paraíba do Norte River Estuary, Brazil.

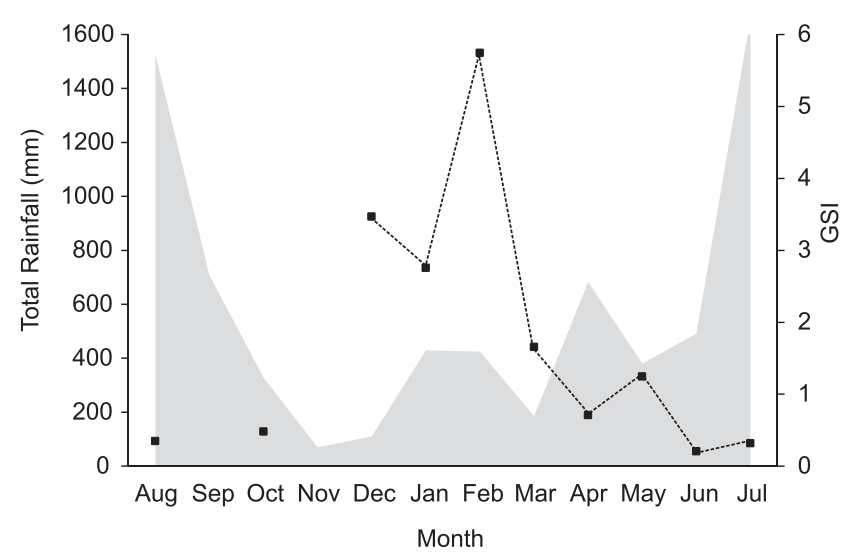

Figure 9. Regional total rainfall (shaded area) and GSI (dashed line) for females of S. herzbergii, between August 2009 and July 2010 in Paraíba do Norte River Estuary, Paraíba, Brazil (INPE/CPTEC 2012).

period, with the greatest rainfall recorded in June. Pearson's correlation between rainfall and GSI values was non-significant $(\mathrm{n}=10 ; \mathrm{r}=-0.453 ; \mathrm{p}=0.09)$.

Mean length at first maturity was approximately $220 \mathrm{~mm}$ for females (Fig. 10) and $231 \mathrm{~mm}$ for males (Fig. 11).

\section{DISCUSSION}

The proportion of $S$. herzbergii females to males caught between August 2009 and July 2010 was 1:1, which is the expected result for most fish species (NiKolsky 1963). According to VAzzoler (1996), the sex ratio may reveal an absence of predominance of one gender over the other when assessing the total catch, but unequal occurrences may be found in monthly assessments. In the present study, significant differences in the sex ratio were found in December and May, when females predominated, and in March, when males predominated. This inequality may result from behavioral differences between the sexes (Vazzoler 1996). Chaves (1994) stressed the importance of correctly managing catfish fisheries, because their peculiar reproductive behavior makes them very dependent on population density.
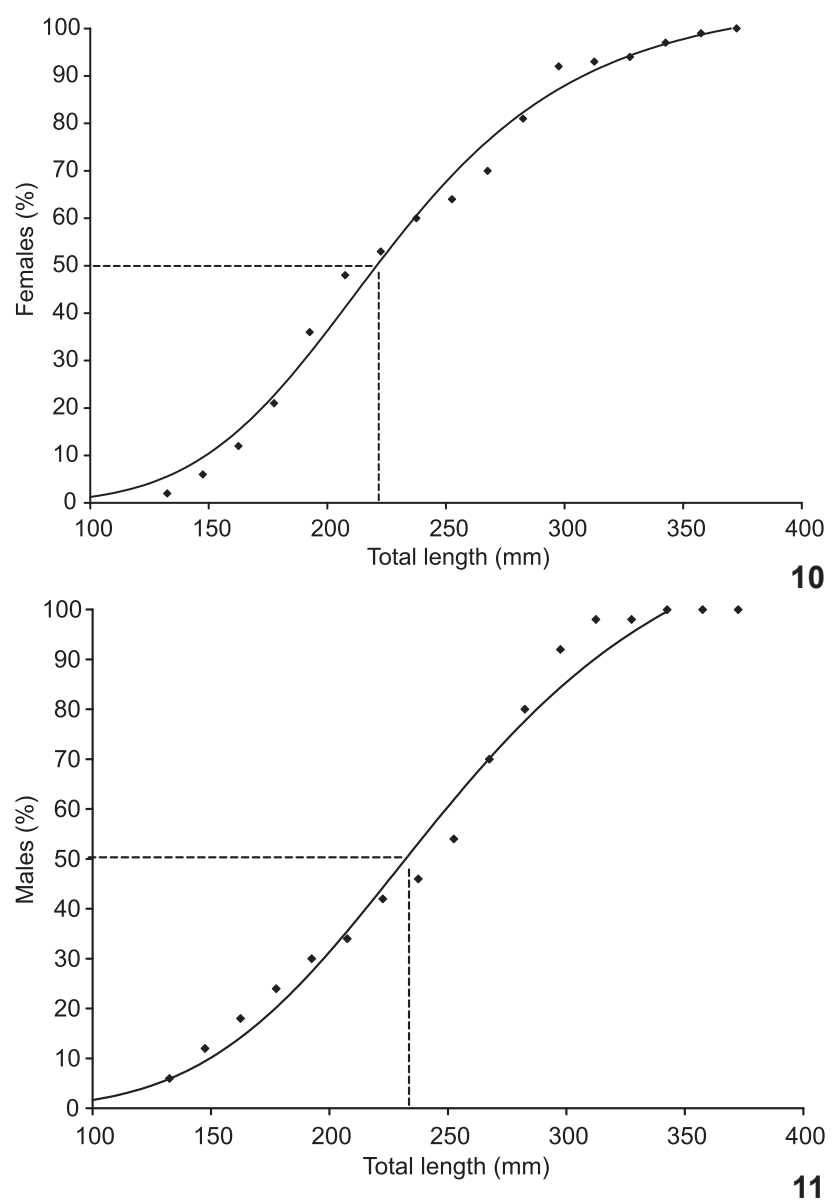

Figures 10-11. Mean length at first maturity $\left(L_{50}\right)$ for $S$. herzbergii females $n=123$ (10) and males $n=105$ (11) in Paraíba do Norte River Estuary, Brazil. 
Based on the occurrence of mature and spawning females and high GSI values, the spawning period for $S$. herzbergii in the study area spans from December to March. Females of this species produce few oocytes. Like in other representatives of the family, the reproductive strategy of $S$. herzbergii tends to K, (Gomes \& Araújo 2004, Fávaro et al. 2005).

With the exception of the prevalence of females in May, males predominated from March to July, although the difference only achieved statistical significance in March. These findings indicate alternations in the sex ratio, which may be associated with the characteristic male behavior of mouth brooding eggs and embryos (CHAves 1994) predominant in the estuary for about two months due to the favorable conditions for offspring development. Among species of the family Ariidae for which parental care does not occur and the participation of males is limited to the fertilization of oocytes, the predominance of females in the population is common (BARBIERI et al. 1992, CANTANHÊDE et al. 2007).

With regard to gonad development, mature females had greater representation in the sampling in December, January and February, whereas only one mature female was captured in March. There was a gradual decrease in the number of mature females and an increase in the number of spawned females, which were more frequent between April and July, with a lower incidence in August. These findings offer further evidence that the spawning period occurs from December to March.

A long spawning period is characteristic of $\mathrm{K}$ strategist species and represents staggered spawning, such as described for Cathorops spixii (AgAssiz 1829), which reproduced from January to April (Gurgel et al. 2000). However, this result does not reflect the type of spawning of Ariidae from the individual standpoint, as females of this family exhibit total spawning (Gomes et al. 1999, Gomes \& Araújo 2004, Fávaro et al. 2005). Thus, histological analysis of the ovaries is recommended for the confirmation of this apparently distinct behavior between the type of spawning of the population and the individual.

Unlike the clear pattern of distribution of male gonad development stages, the pattern of female gonad development was not clear. This could be associated with the small number of males sampled, which may have biased the analysis.

The highest GSI values for $S$. herzbergii females were recorded between December and March. The small catch in February led to the highest standard error. Moreover, only one female was collected in March. Nonetheless, the data suggest that the breeding season for $S$. herzbergii occurs in this interval, as registered for other populations of ariids in northeastern Brazil (Gurgel et al. 2000, Pinheiro et al. 2006). This period coincides with the beginning of rainfall in the region (December and January) and continues with the period of greatest rainfall (May to July). It is probable that spawning activity in the early rainy season favors the development of juveniles, allowing them take advantage of the nursery conditions of the estuary (BLABER et al. 1995) at the peak of the rainy season. This fact suggests that the reproductive activity of $S$. herzbergii follows the general pattern seen in tropical catfishes, which reproduce in the rainy season (RIMMER \& MERRICK 1983).

The GSI for $S$. herzbergii males peaked two months prior to the maturity period for females. Studying populations of the catfish Genidens genidens (VALENCIENNes 1839) and Cathorops spixii in Sepetiba Bay in the state of Rio de Janeiro (Brazil), Gomes et al. (1999) distributed the GSI values in a bi-monthly regimen and found that peak male maturity occurs after that of females. The authors associate this finding with the period of fasting, stemming from the mouth brooding performed by the males. Studying the reproduction of C. spixii in Pinheiros Bay in the state of Paraná (Brazil), Fávaro et al. (2005) determined monthly GSI values and found that the maturity period coincides between sexes, attributing the result of the Gomes et al. (1999) study to the bi-monthly distribution used in the analysis of the data. The present study also determined GSI values on a monthly basis and nonetheless found that peak male maturity did not overlap peak female maturity, which is in agreement with the finding described by Gomes et al. (1999). However, in this study, the peak of maturity in males occurred before the females, which suggests the need for deeper physiological studies.

While the condition factor $(\mathrm{K})$ for $S$. herzbergii females did not exhibit a significant correlation with the GSI, lower coinciding values were found in the period of gonad maturation, indicating the mobilization of energy reserves for ovarian maturation (LIMA-JÚNIOR \& GoITEIN 2006). In males, the $\mathrm{K}$ value was significantly correlated with the GSI. Moreover, the $\mathrm{K}$ value for males exhibited a decline between December and February, which was similar to what was observed with the females. This finding indicated simultaneousness in the energy investment spent on reproduction for males and females, even though the male GSI fluctuated separately from that of females.

The male $\mathrm{K}$ values demonstrated a decreasing tendency beginning in February. This may be associated to the fact that $S$. herzbergii males protect the offspring through mouth brooding, with the embryos maintained in the oropharyngeal cavity (personal observation). While immature males (which constituted the percentage majority in this period) do not participate in mouth brooding, the low mean monthly $\mathrm{K}$ values in this period may be attributed to males in the spawned stage. BARBIERI et al. (1992) report that mouth brooding in Genidens genidens prevents males from feeding, thereby reducing $\mathrm{K}$ values in this period. The same may occur with $S$. herzbergii in Paraíba do Norte River Estuary. CANTANHÊDE et al. (2007) studied the reproduction of Hexanematichthys proops (Valenciennes, 1840), also a catfish on the coast of the state of Maranhão (northern Brazil) and found a reduction in male $\mathrm{K}$ values in the post-spawning months, but did not observe parental care in the species. Moreover, the authors found higher K values for males in comparison to females. This result was also explained 
by the absence of paternal care of the offspring. In the present study, male $\mathrm{K}$ values were discretely lower than those of the females, possibly due to the need for energy allocation females need for oogenesis, as species of Ariidae have the largest oocytes among Osteichthyes (REIS 1986), which requires a greater energy storage capacity in females in comparison to males. The reduction in $\mathrm{K}$ values for males may be explained by mouth brooding, which completely occupies the oropharyngeal cavity. According to Chaves (1994), males likely completely cease to feed during the incubation period.

Mean length at first maturity $\left(\mathrm{L}_{50}\right)$ of $S$. herzbergii was 220 $\mathrm{mm}$ for females and $231 \mathrm{~mm}$ for males. The larger $\mathrm{L}_{50}$ for males may be related to mouth brooding, as males exhibit greater efficiency in this activity (BARBIeri et al. 1992, Chaves 1994).

In summary, the $S$. herzbergii population in Paraíba do Norte River Estuary exhibits reproduction characterized by the spawning activity described as well as the behavior of postspawning offspring care. These factors are a certainly related to the considerable abundance of this species in estuaries. The present investigation is one of the first studies on the reproductive biology of $S$. herzbergii. Further studies on this species are needed, which would enhance both the understanding and preservation of estuarine environments.

\section{ACKNOWLEDGMENTS}

This study received financial support from the Universidade Estadual da Paraíba (UEPB/PROPESQ 153/2008) and Conselho Nacional de Desenvolvimento Científico e Tecnológico (CNPq: PIBIC 2008/2009 and 2009/2010). The authors are grateful to the fisherman Joceílton dos Santos for support in the field, Oliveira P.A. for assistance with the map and Palma, A.R.T. for a critical reading of the manuscript.

\section{LITERATURE CITED}

Albaret, J. \& P.S. Diouf. 1994. Diversité des poisons des lagunes et des estuaries oust-africains. Synthèses géographiques, $p$. 165-177. In: G.G. Teugels; G.F. GuÉgan \& J.J. Albaret (Eds). Biological Diversity of African Fresh and Brackish Water Fishes. Tervuren, Annales du Musée Royal de l'Afrique Centrale, 275p.

Andrade-Tubino, M.F.; A.L.R. Ribeiro \& M. Vianna. 2008. Organização espaço-temporal das ictiocenoses demersais nos ecossistemas estuarinos brasileiros: Uma síntese. Oecologia Brasiliensis 12 (4): 640-661.

Barbieri, L.R.; R.P. Santos \& J.V. Andreata. 1992. Reproductive biology of the catfish, Genidens genidens (Siluriformes, Ariidae), in the Jacarepaguá Lagoon system, Rio de Janeiro, Brazil. Enviroment Biology of Fishes 35: 23-35.

BARLETA, M. \& M.F. Costa. 2009. Living and non-living resources exploitation in a tropical semi-arid estuary. Journal of Coastal Research 56: 317-375.
Barletta, M.; A. Barletta-Bergan; U. Saint-Paul \& G. Hubold. 2003. Seasonal changes in density, biomass, and diversity of estuarine fishes in tidal mangrove creeks of the lower Caeté Estuary (northern Brazilian coast, east Amazon). Marine Ecology Progress Series 256: 217-228.

Blaber, S.J.M. 2000. Tropical estuarine fishes: ecology, exploitation and conservation. Oxford, Blackwell Science, 372p.

Blaber, S.J.M.; Brewer, D.T. \& J.P. Salini. 1995. Fish communities and the nursery role of the shallow inshore waters of a tropical bay in the Gulf of Carpentaria, Australia. Estuarine, Coastal and Shelf Science 40: 177-193.

Cantanhêde, G.; A.C.L. Castro \& E.A. Gubiani. 2007. Biologia reprodutiva de Hexanematichthys proops (Siluriformes, Ariidae) no litoral ocidental maranhense. Iheringia, Série Zoologia, 97 (4): 498-504.

Chaves, P.T.C. 1994. A incubação de ovos e larvas em Genidens genidens (Valenciennes) (Siluriformes, Ariidae) da Baía de Guaratuba, Paraná, Brasil. Revista Brasileira de Zoologia 11 (4): 641-648.

Fávaro, L.F.; F.A. Frehse; R.N.O. Oliveira \& R.S. Júnior. 2005. Reprodução do bagre amarelo, Cathorops spixii (Agassiz) (Siluriformes, Ariidae), da Baía de Pinheiros, região estuarina do litoral do Paraná, Brasil. Revista Brasileira de Zoologia 22 (4): 1022-1029.

Giarrizzo, T. \& U. Krumme. 2007. Spatial differences and seasonal cyclicity in the intertidal fish fauna from four mangrove creeks in a salinity zone of the Curuçá estuary, north Brazil. Bulletin of Marine Science 80 (3): 739-754.

Gomes, I.D. \& F.G. Araújo. 2004. Reproductive biology of two marine catfishes (Siluriformes, Ariidae) in the Sepetiba Bay, Brazil. Revista de Biologia Tropical 52 (2): 143-156.

Gomes, I.D.; F.G. Araújo; M.C.C. Azevêdo \& A.L.M. Pessanha. 1999. Biologia reprodutiva dos bagres marinhos Genidens genidens (Valenciennes) e Cathorops spixii (Agassiz) (Siluriformes, Ariidae), na Baía de Sepetiba, Rio de Janeiro, Brasil. Revista Brasileira de Zoologia 16 (2): 171-180.

Gomes, I.D.; F.G. Araújo; M.C.C. Azevêdo \& A.L.M. Pessanha. 2001. Escala de maturidade e época de reprodução de três bagres marinhos (Siluriformes, Ariidae) na Baía de Sepetiba, RJ. Comunicações do Museu de Ciências da PUC-RS, Série Zoologia, 14 (1): 3-21.

Gurgel, H.C.B.; C.Q. Albuquerque; D.S.L. Souza \& G. Barbieri. 2000. Aspectos da biologia pesqueira em fêmeas de Cathorops spixii do estuário do rio Potengi, Natal/RN, com ênfase nos índices biométricos. Acta Scientiarum 22 (2): 503-505.

INPE/CPTEC. 2012. Proclima: Programa de monitoramento climático em tempo real da Região Nordeste - Análise municipal das componentes do balanço hídrico. Avalaible online at: http://www6.cptec.inpe.br/proclima2/balanco_hidrico/ balancohidrico.shtml [Accessed: 06/VI/2012].

Krumme, U.; U. Saint-Paul \& H. Rosenthal. 2004. Tidal and diurnal changes in the structure of a nekton assemblage in small 
intertidal mangrove creeks in northern Brazil. Aquatic Living Resources 17: 215-229.

Krumme, U.; M. Brenner \& U. Saint-Paul. 2008. Spring-neap cycle as a major driver of temporal variations in feeding of intertidal fishes: Evidence from the sea catfish Sciades herzbergii (Ariidae) of equatorial west Atlantic mangrove creeks. Journal of Experimental Marine Biology and Ecology 367: 91-99.

Lima-Junior, S.E. \& R. Goitein. 2006. Fator de condição gonadal de fêmeas de Pimelodus maculatus (Osteichthyes, Pimelodidae) no Rio Piracicaba (SP, Brasil). Boletim do Instituto de Pesca 32 (1): 87-94.

MarceniuK, A.P. 2005. Chave para identificação das espécies de bagres marinhos (Siluriformes, Ariidae) da costa brasileira. Boletim do Instituto de Pesca 31 (2): 89-101.

Marceniuk, A.P. 2007. Revalidação de Cathorops arenatus e Cathorops agassizii (Siluriformes, Ariidae), bagres marinhos das regiões norte e nordeste da América do Sul. Iheringia, Série Zoologia, 97 (4): 360-375.

Submitted: 07.III.2012; Accepted: 27.VI.2012.

Editorial responsibility: Cassiano Monteiro Neto
Nikolsky, G.V. 1963. The ecology of fishes. New York, Academic press, $\mathrm{XV}+352 \mathrm{p}$.

Pinheiro, P.; M.K. Broadhurst; F.H.V. Hazin; T. Bezerra \& S. HamilTON. 2006. Reproduction in Bagre marinus (Ariidae) off Pernambuco, northeastern Brazil. Journal of Applied Ichthyology 22: 189-192.

ReIs, E.G. 1986. Reproduction and feeding habits of the marine catfish Netuma barba (Siluriformes, Ariidae), in the estuary of Lagoa dos Patos, Brasil. Atlântica 8: 35-55.

Rimmer, M.A.N. \& J.R. Merrick. 1983. A review of reproduction and development in the fork-tailed catfishes (Ariidae). Proceedings of the Limnology Society 107: 41-50.

VAzzoler, A.E.A.M. 1996. Biologia da reprodução de peixes teleósteos: teoria e prática. Maringá, EDUEM, 169p.

Vendel, A.L.; J.L. Bouchereau \& P.T. Chaves. 2010. Environmental and subtidal fish assemblage relationships in two different Brazilian coastal estuaries. Brazilian Archives of Biology and Technology 53: (6): 1393-1406. 